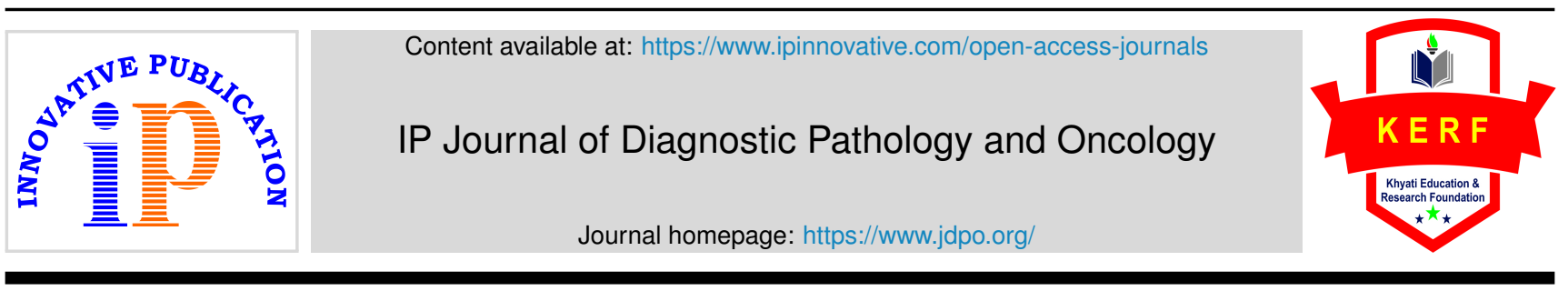

Original Research Article

\title{
To differentiate between different types of anaemia morphologically and its distribution in different age groups and sex
}

\author{
Dupinder Kaur ${ }^{1} *$, Pooja Agarwal ${ }^{1}$ \\ ${ }^{1}$ Dept. of Pathology, Shri Ram Murti Smarak Institute Of Medical Sciences, Bareilly, Uttar Pradesh, India
}

\section{A R T I C L E I N F O}

\section{Article history:}

Received 09-01-2021

Accepted 14-01-2021

Available online 10-03-2021

\section{Keywords:}

Anaemia

Morphologically

Age \& Sex

\begin{abstract}
A B S T R A C T
Background \& Methods : Males who attended various departmental OPDs at tertiary care centre, and inpatients participated in this study as per the inclusion and exclusion criteria. Blood was withdrawn from an cubital vein by mean of dry sterile 5mldisposable plastic syringe with a needle of 20 guage after preparing the cubital fossa with a sterile swab, $3 \mathrm{ml}$ of blood was withdraw slowly, immediately blood is transferred to sterile tube with di-potassium EDTA as anticoagulant.

Results:Out of 500 cases, 320 cases were male cases and 180 were female cases. Of these 320 male cases, $98(30.63 \%)$ cases had mild anaemia, 189 cases $(59.6 \%)$ had moderate anaemia and 33 cases $(10.31 \%)$ had severe anaemia. Similarly, of 180 female cases, $55(30.56 \%)$ cases had mild anaemia, 101 cases $(56.11 \%)$ had moderate anaemia and 24 cases $(13.33 \%)$ had severe anaemia. Male to female ratio is $1.8: 1$ i.e male outnumbered female in the study. However, the distribution of severity of anaemia did not differ significantly between males and females (P-value>0.05). Out of the 500 cases studied, 50 cases $(10 \%)$ had $>80 \mathrm{fl} \mathrm{MCV}, 319$ cases $(63.80 \%)$ had MCV between $59-80 \mathrm{fl}$ and 131 cases $(26.20 \%)$ had <59 fl MCV. However, MCV $<59$ fl noted maximally i.e. $34.75 \%$ in $0-5$ years age group. The distribution of MCV with age varied significantly ( $\mathrm{p}$ value $<0.05$ ).

Conclusions: Anemia is the most common problem occurring in males in our country, due to various reasons. Prevalence is being higher in Indian scenario, as compared to developed countries. Hence, it is recommended that, this age group is compulsorily screened for anaemia. Study of morphological pattern of anaemia directs us to the further management of underlying etiology.

(C) This is an open access article distributed under the terms of the Creative Commons Attribution License (https://creativecommons.org/licenses/by/4.0/) which permits unrestricted use, distribution, and reproduction in any medium, provided the original author and source are credited.
\end{abstract}

\section{Introduction}

The discovery of mathematically derived RBC indices from Wintrobe's hematocrit gave us the mean corpuscular volume (MCV), mean corpuscular hemoglobin concentration (MCHC), and mean corpuscular hemoglobin $(\mathrm{MCH}){ }^{1}$ While the meticulous morphological observations of the earlier hematologists have largely remained unchanged, recent mechanical approaches have provided inroads into accurate, precise, and reproducible counts of all the blood cells. Although sophisticated blood cell counting devices rapidly generate hematologic data, correlation with clinical findings and patient history is required for an accurate

\footnotetext{
* Corresponding author.

E-mail address: dupindercaur@gmail.com (D. Kaur).
}

diagnosis. $^{2}$

The development of knowledge of iron deficiency anaemia and therapeutic use of iron was mentioned in Greek mythology in the story of 'Iphiclus' who was cured of impotence by drinking iron rust dissolved in wine. Much of the iron therapy used by ancient physicians had its origin in such sympathetic magic, the sufferer hoping to assume the strength of steel by drinking water or wine in which a sword had rusted. ${ }^{3}$

Iron deficiency anaemia in males occurs most frequently between the age of 6 months to 3 years and 11 to 17 years. It is a major health problem in males. About $51 \%$ of males in $0-4$ years and $46 \%$ of males in the 5-12 years age group are anaemic in the developing countries. ${ }^{4}$ 
Iron deficiency is the most widely recognized medical problem on the planet, and it influences an enormous populace in practically all nations. The most incessant etiologies of frailty are healthful insufficiencies, intestinal sickness, parasitic diseases, blood misfortune, bone marrow substitution, or concealment furthermore, hemoglobinopathies. ${ }^{5}$ Arbitrarily, paleness might be named either moderate $(7.0-10.0 \mathrm{~g} / \mathrm{dl})$ or extreme $(<7.0$ $\mathrm{g} / \mathrm{dl}$ ). The signs furthermore, indications of paleness are for the most part vague, for example, weariness what's more, shortcoming; it is frequently connected with gastrointestinal indications for example, queasiness, clogging, or diarrhea. ${ }^{6}$

Normocytic hypochromic red cells have the focal territory of polar possessing about $33 \%$ of the cell measurement and show decreased staining, with an increment in the focal zone of the pallor. ${ }^{5}$ The morphological order of pallor depends on morphological measures of red cells in ideal slim blood film, and furthermore on red cells lists, mean corpuscular volume $(\mathrm{MCV})$, mean cell hemoglobin $(\mathrm{MCH})$ and $\mathrm{MCH}$ focus (MCHC). This investigation is led to decide the most widely recognized morphological examples of sickliness among the Saudi pallid populace, and this will give a decent sign about the primary reason for sickliness among such patients, other than planning a decent convention for conclusion.

\section{Materials and Methods}

All the blood samples from males below 15 years reported by the Department in our institution during the study period with 500 samples.

It is a hospital based cross sectional study. Males who attended various departmental OPDs at tertiary care centre, and inpatients participated in this study as per the inclusion and exclusion criteria.

Blood was withdrawn from an cubital vein by mean of dry sterile 5 mldisposable plastic syringe with a needle of 20 guage after preparing the cubital fossa with a sterile swab, $3 \mathrm{ml}$ of blood was withdraw slowly, immediately blood is transferred to sterile tube with di-potassium EDTA as anticoagulant.

\subsection{Inclusion criteria $^{5}$}

All males of:

1. Age group: below 15 years.

2. Those who full fill the WHO criteria for Anaemia.

3. Those males with hemoglobin $<11 \mathrm{gm} / \mathrm{dl}$.

\subsection{Exclusion criteria}

1. Males above 15 year of age

2. Hemoglobin above $11 \mathrm{gm} / \mathrm{dl}$

\subsection{Signs and Symptoms of the Anemias}

A. The main symptoms are due to cardiovascular system adaptation. There are increased stroke volume and tachycardia and changes in the $\mathrm{Hb} \mathrm{O} 2$ dissociation curve.

1. There is hyperdynamic circulation leading to tachycardia, a bounding pulse, systolic murmurs, especially at the apex, and cardiomegaly.

2. Older adults may find $\mathrm{S} / \mathrm{S}$ of congestive heart failure.

B. In some of the patients with anemia, there is no $\mathrm{S} / \mathrm{S}$, while mild anemia may have severe S/S.

C. Acute onset effect: There is an effect of the speed of onset; in case of acute onset has more $\mathrm{S} / \mathrm{S}$ in comparison to the slow onset.

D. The severity of the anemia: In the case of mild anemia, there is no $\mathrm{S} / \mathrm{S}$.

When the $\mathrm{Hb}$ is $<9$ to $10 \mathrm{~g} / \mathrm{dL}$, it may show $\mathrm{S} / \mathrm{S}$.

Even $\mathrm{Hb}$ as low as $6 \mathrm{~g} / \mathrm{dL}$ may not produce severe $\mathrm{S} / \mathrm{S}$.

E. Age: The older people tolerate less as compare to young people

F. $\mathrm{Hb} \mathrm{O} 2$ dissociation curve: The RBCs carry $\mathrm{O} 2$ from the lung to the tissue and bring $\mathrm{CO} 2$ in the venous blood to the lung. This is dependant upon the 2,3-diphosphoglycerate (2,3-DPG). When the $\mathrm{O} 2$ is unloaded, the $\beta$-chain of $\mathrm{Hb}$ has pulled apart, permitting the entry of the metabolites 2,3$\mathrm{DPG}$ resulting in a lower affinity of the molecule for $\mathrm{O} 2$.

\subsection{Normally $\mathrm{O} 2$ exchange takes place}

$95 \%$ saturated arterial blood with a mean arterial $\mathrm{O} 2$ tension of $95 \mathrm{mmHg}$.

$70 \%$ saturated venous blood with a mean venous $\mathrm{O} 2$ tension of $40 \mathrm{mmHg}$.

So the curve's normal position depends upon the concentration of 2,3-DPG, $\mathrm{H}+$ ions, and $\mathrm{CO} 2$ in the RBCs and on the $\mathrm{Hb}$ molecule structure.

\section{Results}

Table 1: Age wise and gender wise distribution of cases

\begin{tabular}{|c|c|c|c|c|c|c|c|c|}
\hline \multicolumn{3}{|c|}{ Gender0-5 years } & \multicolumn{2}{|c|}{$\begin{array}{c}\text { Age Group } \\
\text { 6-10 years }\end{array}$} & \multicolumn{2}{|c|}{$\begin{array}{l}11-15 \\
\text { years }\end{array}$} & \multicolumn{2}{|c|}{ Total } \\
\hline & No. & $\%$ & No. & $\%$ & No. & $\%$ & No. & $\%$ \\
\hline Male & 174 & 67.18 & 77 & 58.78 & 69 & 62.73 & 320 & 64.00 \\
\hline Femal & e 85 & 32.82 & 54 & 41.22 & 41 & 37.27 & 180 & 36.00 \\
\hline Total & 259 & 100 & 131 & 100 & 110 & 100 & 500 & 100 \\
\hline
\end{tabular}

Pearson Chi-Square $=2.765, \mathrm{DF}=2, \mathrm{P}$-Value $=0.251$

Out of total 500 cases, $320(64 \%)$ cases were males and $180(26 \%)$ cases were females. Maximum male cases were of $0-5$ years i.e. 174 cases $(67.18 \%)$ out of total 259 cases under the age group. Female cases showed maximum proportion $(41.22 \%)$ in 6-10 year age group. 
Table 2: Gender wise Distribution of Cases according to Hemoglobin level

\begin{tabular}{lcccccc}
\hline \multirow{2}{*}{ Hb } & \multicolumn{4}{c}{ Sex } & \multicolumn{3}{c}{ Total } \\
Grading & \multicolumn{2}{c}{ Female } & \multicolumn{2}{c}{ Male } & No. & $\%$ \\
& No. & $\%$ & No. & $\%$ & \% & \\
Mild & 55 & 30.56 & 98 & 30.63 & 153 & 30.60 \\
Moderate & 101 & 56.11 & 189 & 59.6 & 290 & 58.00 \\
Severe & 24 & 13.33 & 33 & 10.31 & 57 & 11.40 \\
Total & 180 & 100 & 320 & 100 & 500 & 100 \\
\hline
\end{tabular}

Pearson Chi-Square $=1.095, \mathrm{DF}=2, \mathrm{P}$-Value $=0.578$

Out of 500 cases, 320 cases were male cases and 180 were female cases. Of these 320 male cases, 98 $(30.63 \%)$ cases had mild anaemia, 189 cases $(59.6 \%)$ had moderate anaemia and 33 cases $(10.31 \%)$ had severe anaemia. Similarly, of 180 female cases, $55(30.56 \%)$ cases had mild anaemia, 101 cases $(56.11 \%)$ had moderate anaemia and 24 cases $(13.33 \%)$ had severe anaemia. Male to female ratio is 1.8:1 i.e male outnumbered female in the study. However, the distribution of severity of anaemia did not differ significantly between males and females (Pvalue $>0.05)$.

Table 3: Age wise Distribution of Cases according to Mean Corpuscular Volume (MCV) unit= femtolitre (fl)

\begin{tabular}{|c|c|c|c|c|c|c|c|c|}
\hline \multirow[t]{2}{*}{$\begin{array}{l}\text { MCV } \\
\text { Group }\end{array}$} & \multicolumn{2}{|c|}{ 0-5 years } & \multicolumn{2}{|c|}{$\begin{array}{c}\text { Age Group } \\
6-10 \\
\text { years }\end{array}$} & \multicolumn{2}{|c|}{$\begin{array}{l}11-15 \\
\text { years }\end{array}$} & \multicolumn{2}{|c|}{ Total } \\
\hline & No. & $\%$ & No. & $\%$ & No. & $\%$ & No. & $\%$ \\
\hline $\begin{array}{l}<59 \\
\mathrm{fl}\end{array}$ & 90 & 34.75 & 30 & 22.90 & 11 & 10.00 & 131 & 26.20 \\
\hline $\begin{array}{l}59- \\
80 \\
\text { fl }\end{array}$ & 148 & 57.14 & 89 & 67.94 & 82 & 74.55 & 319 & 63.80 \\
\hline $\begin{array}{l}>80 \\
\mathrm{fl}\end{array}$ & 21 & 8.11 & 12 & 9.16 & 17 & 15.45 & 50 & 10.00 \\
\hline Total & 259 & 100 & 131 & 100 & 110 & 100 & 500 & 100 \\
\hline
\end{tabular}

Pearson Chi-Square $=27.221, \mathrm{DF}=4, \mathrm{P}-$ Value $=0.000$

Out of the 500 cases studied, 50 cases $(10 \%)$ had $>80 \mathrm{fl}$ MCV, 319 cases $(63.80 \%)$ had MCV between 59-80 fl and 131 cases $(26.20 \%)$ had $<59$ fl MCV. However, MCV $<59$ $\mathrm{fl}$ noted maximally i.e. $34.75 \%$ in $0-5$ years age group. The distribution of MCV with age varied significantly ( $\mathrm{p}$ value $<0.05)$.

\section{Discussion}

Pediatric anaemia is an important universal problem. ${ }^{7}$ Nutritional anaemia is a well known public health problem worldwide. In India, anaemia is affecting more than half of total population, particularly males and pregnant women. ${ }^{8,9}$

Nutritional status of infants largely depends upon the mother's nutritional status. Most males with anaemia are asymptomatic. Iron deficiency is the most common form of nutritional deficiency resulting in increased mortality and morbidity. It is the most common hematologic disease in infants and males worldwide. ${ }^{10-12}$ One of the major areas for improvement in primary care is prevention of nutritional deficiency anaemia, as it has been associated with visual and auditory dysfunction, cognitive and behavioral abnormalities and delay in psychomotor development. Hence, its prevention in early childhood is an important health issue. ${ }^{13,14}$

In this study the cases who fulfilled the WHO criteria were taken and divided on the basis of age, gender and other parameters. Cases from 0-15 years of age were taken and grouped as: 0-5 years, 6-10 years and $11-15$ years. ${ }^{15}$

\section{Conclusion}

Anemia is the most common problem occurring in males in our country, due to various reasons. Prevalence is being higher in Indian scenario, as compared to developed countries. Hence, it is recommended that, this age group is compulsorily screened for anaemia. Study of morphological pattern of anaemia directs us to the further management of underlying etiology.

\section{Source of Funding}

No financial support was received for the work within this manuscript.

\section{Conflict of Interest}

The authors declare they have no conflict of interest.

\section{References}

1. Robbins C. Red blood cell and bleeding disorders. In: Kumar V, Abbas A, Fausto N, Aster J, editors. Pathologic Basis of Diseases. 8th Edn. Philadelphia: Elsevier; 2010. p. 640.

2. Rappaport E, Helbert B, Beissner R, Trowbridge A. Automated Hematology: Where We Stand. Southern Med J. 1988;81(3):365-70.

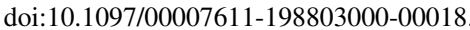

3. Frazer JG. The golden bough. The magic art in the evolution of kings. New York: Macmillan; 1935. p. 158.

4. Hoffbrand AV. Erythropoiesis and general aspects of anemia. In: Hoffbrand A, Pettit J, editors. Essential Haematology. 3rd edn. Oxford: Blackwell Scientific; 1993. p. 12-35.

5. Lindenbaum J. An approach to the anemias. In: Wyngaarden J, editor. Cecil Textbook of Medicine. 19th edn.. vol. 1. Philadelphia: WB Saunders; 1992. p. 822-31.

6. Corrons JLV. La anemia, aspectos enerals del diagnóstico. In: SansSabrafen J, Raebel CB, Corrons JV, editors. Hematología Clínica. 5th edn. Spain: Madrid: Elsevier; 2006. p. 107-26

7. Sharada B. Iron deficiency and iron deficiency anaemia. Recent Adv Maless. 1995;5:205-33.

8. Christensen RD, Henry E, Jopling J, Wiedmeier SE. The CBC: Reference Ranges for Neonates. Semin Perinatol. 2009;33(1):3-11. doi:10.1053/].semperi.2008.10.010.

9. Miller CJ, Dunn EV, Berg B, Abdouni SF. A hematological survey of preschool males of the United Arab Emirates. Saudi Med J. 2003;24(6):609-13.

10. Chen AWU, Respirance L, Birnstein H. Screening for iron deficiency. Ped Rev. 2002;23(5):171-7. 
11. Brotanek JM, Gosz J, Weitzman M, Flores G. Iron Deficiency in Early Childhood in the United States: Risk Factors and Racial/Ethnic Disparities. Pediatr. 2007;120(3):568-75. doi:10.1542/peds.2007-

$$
0572
$$

12. Kapur D, Agarwal KN, Sharma S, Kela K, Kaur I. Iron status of males aged 9-36 months in an urban slum integrated child development service project in Delhi. Indian Ped. 2002;39:136-44.

13. Sindhu S, Kumari K, Uppal M. Prevalence of anemia in schedule caste preschool males of Punjab. Indian J Med Sci. 2002;56(5):218-21.

14. Stellinga-Boelen AAM, Storm H, Wiegersma PA, Bijleveld CMA, Verkade HJ. Iron Deficiency Among Children of Asylum Seekers in The Netherlands. J Pediatr Gastroenterol Nutr. 2007;45(5):591-5. do1:10.1097/mpg.0b013e31810e76as.

15. Muthusamy BG, Venugopal V, Sumithra S. Prevalence of anaemia among the hospitalized children in a rural tertiary care teaching hospital. Int J Contemp Pediatr. 2017;4(2):431-7. ब01:0. 18203/2349 3291.1jcp20170683.

\section{Author biography}

Dupinder Kaur, Resident

Pooja Agarwal, Resident

Cite this article: Kaur D, Agarwal P. To differentiate between different types of anaemia morphologically and its distribution in different age groups and sex. IP J Diagn Pathol Oncol 2021;6(1):54-57. 